\title{
Impacts of end-use energy efficiency measures on life cycle primary energy use in an existing Swedish multi-story apartment building
}

\author{
Ambrose Dodoo $^{1, *}$, Leif Gustavsson ${ }^{1,2}$, Roger Sathre ${ }^{1}$ \\ ${ }^{1}$ Mid Sweden University, 83125 Östersund, Sweden \\ ${ }^{2}$ Linnaeus University, 35195 Växjö, Sweden \\ *Corresponding author. Tel: +46 63165383, Fax:+46 63165500,E-mail: ambrose.dodoo@miun.se
}

\begin{abstract}
In this study we analyze the effects of energy efficiency measures on the life cycle primary energy use of a case-study (reference) 4-story wood-frame apartment building using electric resistance heating, bedrock heat pump, or cogeneration-based district heating. The reference building has an annual final heat energy demand of $110 \mathrm{kWh} / \mathrm{m}^{2}$. The energy efficiency measures analyzed are improved windows and doors, increased insulation in attic and exterior walls, installation of improved water taps, and installation of a heat recovery unit in the ventilation system. We follow the buildings' life cycles and calculate the primary energy use during the production, retrofitting, operation and end-of-life phases, and the energy reduction achieved by the measures. The results show that the measures give significantly greater life cycle primary energy savings when using resistance heating than when using district heating. However, a resistance heated building with the efficiency measures still has greater life cycle primary energy use than a district heated building without the measures. Ventilation heat recovery is the most effective measure when using resistance heating while improved windows and doors is the most effective when using district heating. This study shows the importance of considering the interactions between individual measures and the type of heat supply system when selecting energy efficiency measures.
\end{abstract}

Keywords: Life cycle, Primary energy, End-use energy efficiency measures, Retrofitting, Low energy buildings

\section{Introduction}

The building sector offers significant potential to reduce primary energy use and thereby reduce $\mathrm{CO}_{2}$ emission [1]. Several strategies can be used to realize this potential, e.g. reduced heating demands and increased efficiency in energy supply chains. The construction of new low energy buildings is important in the long term, but has small effect on the building sector's overall energy use in the short term, as the rate of addition of new buildings to the building stock is low [2]. Large potential exists to reduce primary energy use in existing buildings in the short term, through energy efficiency measures. Energy efficiency measures may be implemented at any time in a building's service life, but some measures are more costeffective during major renovation works [3].

The life cycle of a building encompasses production, retrofitting, operation and end-of-life phases, which all are interlinked. The final operation energy use in existing buildings can be reduced considerably by implementing energy efficiency measures, e.g. improved insulation, efficient windows, heat recovery from exhaust ventilation air and efficient appliances. These building retrofitting measures also increase material use and the production energy use. Together that reduce the dominance of the operating phase and other life cycle phases becomes relatively more important [4]. The primary energy use depends on the energy supply systems. The energy supply of a building can be provided by different types of supply systems resulting in a large variation in primary energy use for a given final energy use [5]. Hence, the primary energy savings of energy efficiency measures depend on the energy supply systems. Commonly, the difference in final operation energy use before and after implementing energy efficiency measures is used to estimate the savings from such measures. This is inadequate because the energy implications of implementing energy efficiency measures extend beyond the operation phase. Instead, a comprehensive approach to analyze the savings of energy efficiency measures requires a system-wide perspective, including all life cycle phases of a 
building and the entire energy chains, from natural resources to final energy services.

In this study we analyze the potential final energy savings in an existing Swedish apartment building by energy efficiency measures, and explore the life cycle primary energy implications of implementing the measures. We consider space heating systems using electric resistance heating, heat pump or district heating.

\section{Method}

We calculate the primary energy use for all life cycle phases of a reference building before and after implementing the energy efficiency measures, taking into account the production, retrofitting, operation and end-of-life phases.

\subsection{Case-study building}

The case-study building is a 4-storey wood frame apartment building constructed around 1995 in Växjö, Sweden. It has 4 floors and 16 apartments, and a total heated floor area of $1190 \mathrm{~m}^{2}$. The roof consists of two layers of asphalt-impregnated felt, wood panels, $40 \mathrm{~cm}$ mineral wool between wooden roof trusses, polythene foils and gypsum boards, giving an overall U-value of $0.13 \mathrm{~W} / \mathrm{m}^{2} \mathrm{~K}$. The windows are double glazed and have a U-value of $1.9 \mathrm{~W} / \mathrm{m}^{2} \mathrm{~K}$. The external doors have a U-value of $1.19 \mathrm{~W} / \mathrm{m}^{2} \mathrm{~K}$ and consist of framing with double glazed window panels. The external walls have a U-value of $0.20 \mathrm{~W} / \mathrm{m}^{2} \mathrm{~K}$ and consist of three layers: $5 \mathrm{~cm}$ plaster-compatible mineral wool panels, $12 \mathrm{~cm}$ thick timber studs with mineral wool between the studs, and a wiring and plumbing installation layer consisting of $7 \mathrm{~cm}$ thick timber studs and mineral wool. Two-thirds of the facade is plastered with stucco, while the facades of the stairwells and the window surrounds consist of wood paneling. The ground floor consists of $1.5 \mathrm{~cm}$ oak boarding on $16 \mathrm{~cm}$ concrete slab laid on $7 \mathrm{~cm}$ expanded polystyrene and $15 \mathrm{~cm}$ macadam, resulting in a U-value of $0.23 \mathrm{~W} / \mathrm{m}^{2} \mathrm{~K}$. The construction and thermal characteristics of the building, including the U-values of the components are given by Persson [6].

\subsection{Energy efficiency measures considered}

We model energy efficiency measures to the case-study building to achieve a passive house standard. The energy efficiency measures are shows in Table 1. We calculate the U-values resulting from implementing these measures using the method recommended by Swedisol [7].

Table 1. End-use energy efficiency measures applied

\begin{tabular}{ll}
\hline Description & Effect of improvement \\
\hline Improved taps & Reduced hot water used \\
$15 \mathrm{~cm}$ additional mineral wool insulation to the roof & U-value from 0.13 to 0.08 \\
Windows replaced by triple glazed units (krypton filled) & U-value from 1.9 to 0.90 \\
Doors replaced by triple glazed units (krypton filled) & U-value from 1.19 to 0.90 \\
$25 \mathrm{~cm}$ additional mineral wool insulation to external walls & U-value from 0.20 to 0.10 \\
Incorporation of heat recovery unit in the ventilation system & Reduced ventilation heat loss \\
\hline
\end{tabular}

We use simplified assumptions when modeling the measures for the building. For the exterior walls, we assume that the additional $25 \mathrm{~cm}$ mineral wool insulation is added to the exterior façade of the building, and covered by new stucco and plasterboard cladding supported by wooden studs spaced at $0.6 \mathrm{~m}$ apart. We assume that the original roof overhang is sufficient to cover the wider walls. For the roof, we assume that the additional $15 \mathrm{~cm}$ mineral wool insulation can be installed in the existing attic space. We assume that the ventilation heat 
recovery unit with $85 \%$ efficiency is installed and that the ventilation ducts for incoming air can be fitted in the buildings [8]. Based on data from the Swedish Energy Agency [9], we assume that final energy for tap water heating is reduced by $40 \%$ by changing from conventional to efficient water taps.

\subsection{Production and retrofitting phases}

During the production and retrofitting phases we account for all the materials used in the building, including the initial construction and the energy efficient retrofitting. We calculate the primary energy used to extract, process, transport and assemble the materials, and also the available bioenergy recovered from biomass residues in the wood product chain [10]. The specific end-use energy for building material production is based on two Swedish studies [11, 12]. The on-site construction energy used to assemble the building material is estimated using data from Adalberth [13]. We assume that the on-site energy used for the retrofitting work is proportionally equal to the on-site energy used for the initial building construction, weighted by the relative amounts of energy used to produce the building materials used in the reference building and in the improved building. For calculations of biofuel recoverable from biomass residues we use data from Lehtonen et al. [14] and Sathre [10]. To convert end-use energy for material production to primary energy, we use fuel cycle loss values of $10 \%$ for coal, $5 \%$ for oil and 5\% for natural gas, and we assume electricity comes from coal-fired plants [15].

\subsection{Operation phase}

During the operation phase, we consider the primary energy used for space heating, ventilation, domestic hot water, and household electricity. We model the operating energy of the building before and after applying each of the energy efficiency measures, to determine the final energy savings from the measures. The reference building was built in 1995, and we model the pre-retrofitting operating energy use for 15 years. We assume the retrofitting takes place in 2010, and we assume a building lifespan of 50 year after retrofitting. The final energy for space heating, ventilation, domestic hot water and household electricity are modeled using ENORM software [16]. We assume an indoor temperature of $22^{\circ} \mathrm{C}$ and use climate data for Växjo, in southern Sweden. The average annual maximum and minimum temperatures of Växjo are 28 and $-18{ }^{\circ} \mathrm{C}$, respectively.

To quantify the primary energy required to meet the final operation energy use we use the ENSYST software [17], which calculates primary energy use considering the entire energy chains from natural resource extraction to final energy supply. We analyze cases where heat is delivered by electric resistance heating, heat pump or district heating. For the electric resistance heating and heat pump, 95\% of the electricity is assumed to be supplied from standalone biomass steam turbine (BST) plants and the remaining from light-oil gas turbine plants. For district heating, $90 \%$ of the district heat production is assumed to be supplied from combined heat and power (CHP) BST plant, with oil boilers accounting for the remainder. We credit the cogenerated electricity to the district heat plant assuming that it replaces electricity produced from a stand-alone plant with similar technology and fuel [18].

\subsection{End-of-life phase}

We assume that the building is demolished after its service life, with the concrete, steel and wood materials recovered. We calculate the net end-of-life primary energy use as the primary energy used to disassemble and transport the building materials, minus the primary energy benefits from the recovered concrete, steel and wood. We follow the methodology developed by Dodoo et al. [4], and use data from Adalberth [13] and Björklund and Tillman [12]. 


\section{Results}

Table 2 shows the final and primary energy use for heating and ventilating of the reference building and after applying each of the energy efficiency measures to the building. The measures cumulatively decrease the primary energy use by $61 \%, 52 \%$ and $39 \%$ for the resistance heating, heat pump and district heating scenarios, respectively. Heat recovery of ventilation air gives the biggest single decrease in primary energy use when using resistance heaters and heat pump, while efficient windows and doors give the highest primary energy savings when using district heating. The use of heat recovery ventilation system also increases the electricity use, reducing the primary energy savings of ventilation heat recovery. For district heating system mainly based on CHP production, a reduced heat use also reduces the potential production of electricity.

Table 2. Annual final and primary energy use $\left(\mathrm{kWh} / \mathrm{m}^{2}\right)$ for operation after implementation of different measures. Each successive measure includes the effects of all previous measures.

\begin{tabular}{|c|c|c|c|c|c|c|c|}
\hline \multirow[t]{2}{*}{$\begin{array}{l}\text { Applied end-use energy } \\
\text { efficiency measures }\end{array}$} & \multicolumn{4}{|c|}{$\begin{array}{c}\text { Final energy use for different } \\
\text { energy services }\end{array}$} & \multicolumn{3}{|c|}{$\begin{array}{l}\text { Total Primary energy use } \\
\text { for space and tap water } \\
\text { heating, and ventilation }\end{array}$} \\
\hline & $\begin{array}{l}\text { Space } \\
\text { heating }\end{array}$ & $\begin{array}{c}\text { Tap } \\
\text { water } \\
\text { heating }\end{array}$ & $\begin{array}{c}\text { Venti- } \\
\text { lation } \\
\text { electricity }\end{array}$ & Total & $\begin{array}{l}\text { Resistance } \\
\text { heating }\end{array}$ & $\begin{array}{l}\text { Heat } \\
\text { pump }\end{array}$ & $\begin{array}{l}\text { District } \\
\text { heating }\end{array}$ \\
\hline Reference & 70 & 40 & 4 & 114 & 340 & 109 & 72 \\
\hline +Improved taps & 70 & 24 & 4 & 98 & 293 & 95 & 63 \\
\hline $\begin{array}{l}\text { + Additional roof } \\
\text { insulation }\end{array}$ & 69 & 24 & 4 & 97 & 290 & 94 & 63 \\
\hline $\begin{array}{l}\text { + Improved } \\
\text { windows/doors }\end{array}$ & 51 & 24 & 4 & 79 & 236 & 78 & 53 \\
\hline $\begin{array}{l}\text { + Additional external } \\
\text { walls insulation }\end{array}$ & 43 & 24 & 4 & 71 & 212 & 71 & 49 \\
\hline+ Ventilation heat recove & ry 13 & 24 & 8 & 45 & 134 & 57 & 44 \\
\hline
\end{tabular}

Table 3 shows the net primary energy used for the production of the building in the reference and the improved cases. The primary energy balance for the improved building comprises the initial construction primary energy plus the additional primary energy due to the energy efficient retrofitting. Material production primary energy use increases by about $17 \%$ when the measures are cumulatively applied.

Table 3. Production primary energy balances for the reference building and the improved building with all the energy efficiency measures applied.

\begin{tabular}{lcc}
\hline Description & \multicolumn{2}{c}{ Primary energy used $\left(\mathrm{kWh} / \mathrm{m}^{2}\right)$} \\
\cline { 2 - 3 } & Reference & Improved \\
\hline Production of building materials & 579 & 680 \\
On-site construction work & 50 & 59 \\
Recovered biomass residues & -345 & -355 \\
Total & $\mathbf{2 8 4}$ & $\mathbf{3 8 4}$ \\
\hline
\end{tabular}

Fig. 1 shows the primary energy use during 50 years of operation of the reference building and the improved building with all the measures implemented when using BST supply technology. In the improved building the primary energy for space and water heating decreases, but that for ventilation increases, as additional electricity is used to run the heat recovery ventilation system. The cumulatively applied measures results in greater decrease in 
operation primary energy in the cases where the building is heated with electricity. However, the reference building with district heating has lower operating primary energy than the improved building with resistance heating. Thus, the type of heat supply has greater impact on primary energy use than do the energy efficiency measures.

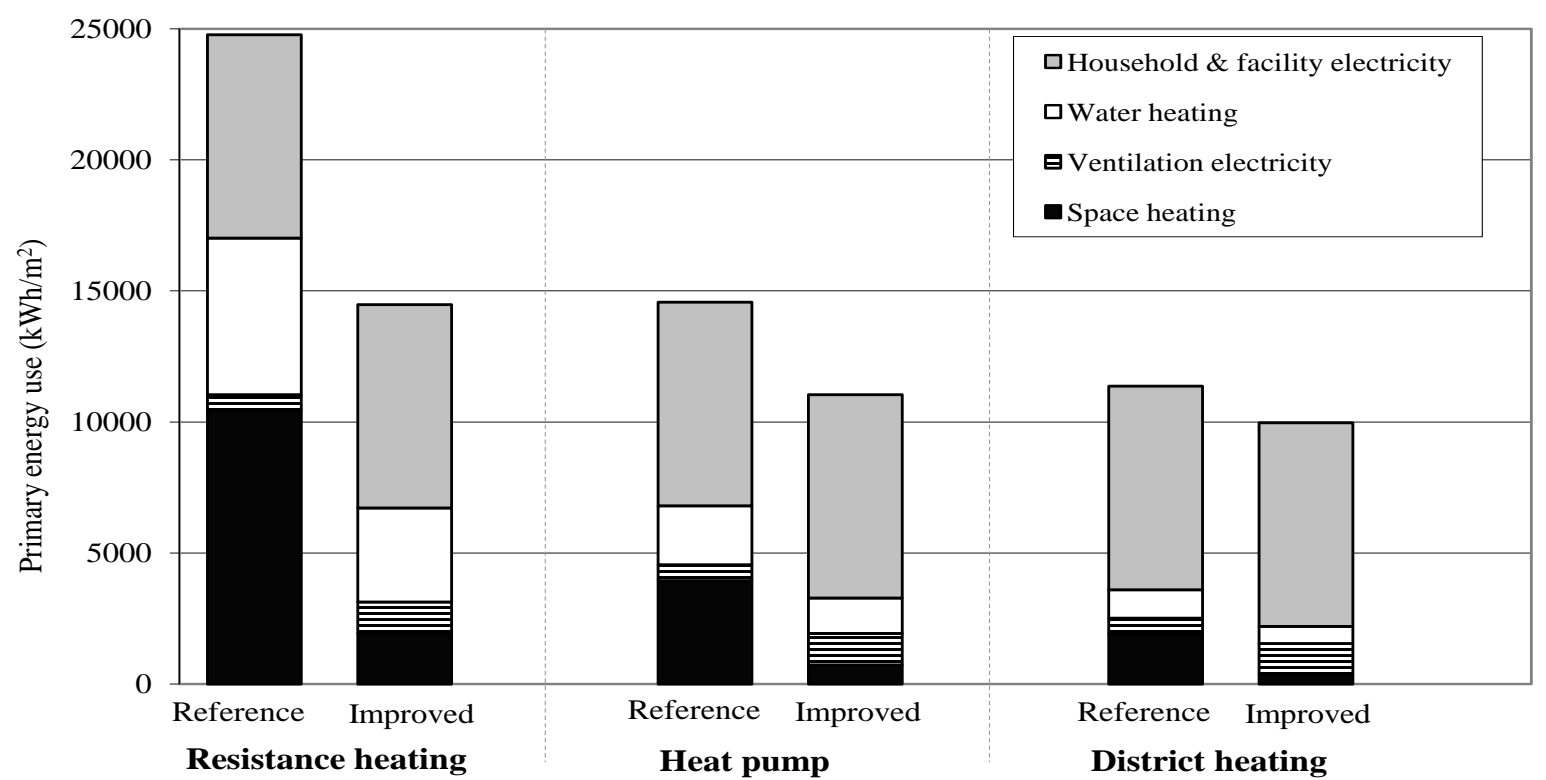

Fig 1. Primary energy use for building operation for 50 years, for the reference building and the improved building with all the measures cumulatively applied.

Table 4 shows the primary energy balances of the end-of-life phase of the buildings. Recovery of wood for use as biofuel gives the greatest end-of-life primary energy benefit, followed by recycling steels to replace ore-based steel. Recycling of concrete as crushed aggregate gives a minor end-of-life primary energy benefit.

Table 4. End-of-life primary energy balances for the reference building and the improved building with all the energy efficiency measures applied.

\begin{tabular}{lcc}
\hline Description & \multicolumn{2}{c}{ Primary energy used $\left(\mathrm{kWh} / \mathrm{m}^{2}\right)$} \\
\cline { 2 - 3 } & Reference & Improved \\
\hline Disassembly & 5 & 5 \\
Concrete recovery for crushed aggregate & -3 & -3 \\
Steel recovery for feedstock & -60 & -60 \\
Wood recovery for fuel & -305 & -311 \\
Total & $\mathbf{3 6 3}$ & $\mathbf{3 6 9}$ \\
\hline
\end{tabular}

Fig. 2 shows the development over time of the primary energy use of the building with and without the energy efficient retrofitting for space and tap water heating and ventilation. The construction of the building in 1995 uses $579 \mathrm{kWh} / \mathrm{m}^{2}$ of primary energy, while $345 \mathrm{kWh} / \mathrm{m}^{2}$ of bioenergy can be recovered from biomass residues. From 1995 to 2010, energy is used for space and tap water heating and ventilation of the reference building, and is greater for the resistance heated building than for the building with district heating or heat pump. In 2010, additional energy is used to retrofit the buildings. The primary operation energy from 2010 to 2060 is significantly lower if the building is improved. The energy "pay-back period" for the energy used for retrofitting is short. The net life cycle energy benefit of the improvement is the difference between the unmarked and the corresponding marked lines at the year 2060 . The benefit is positive in all cases and is greatest when the building uses electric resistance heating. 


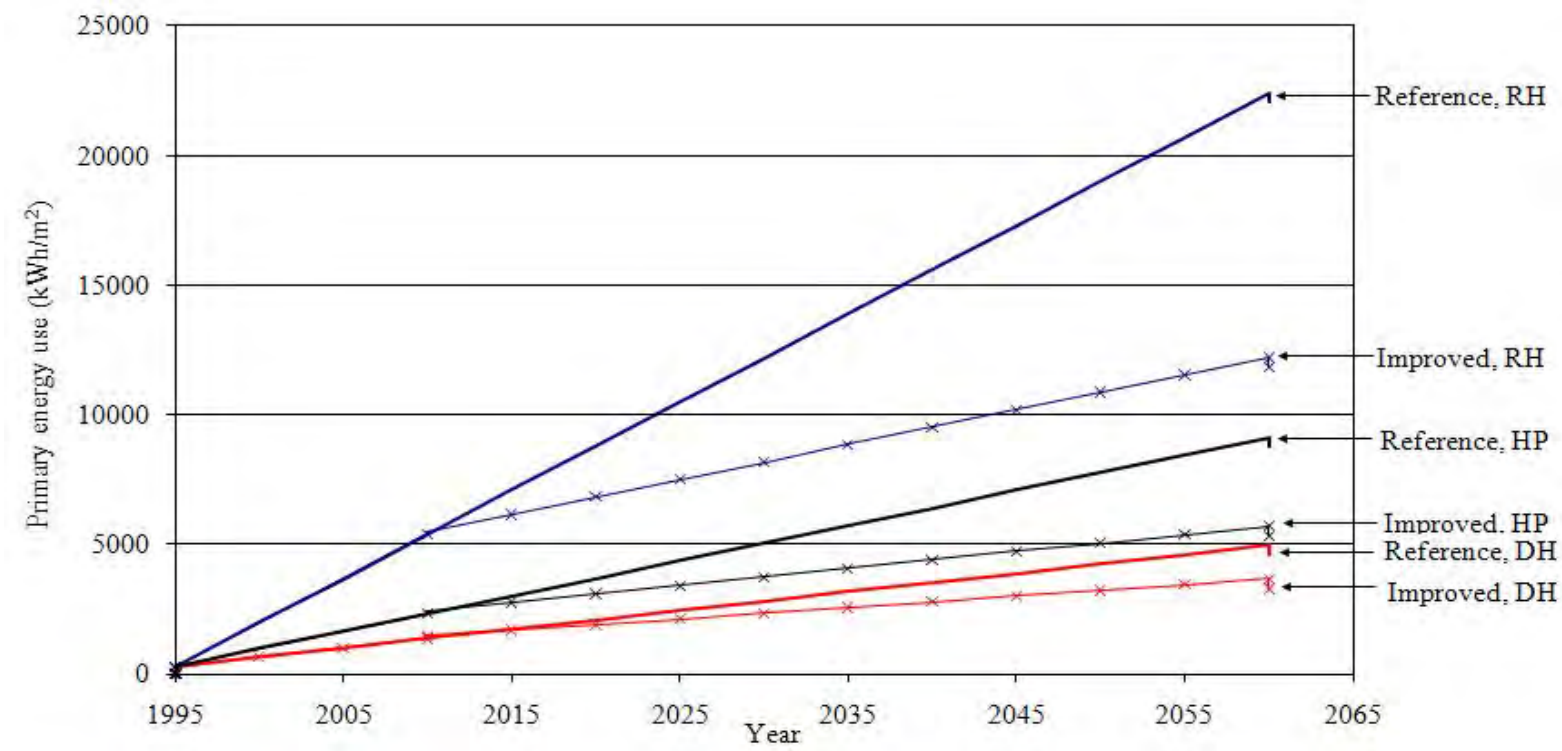

Fig 2. Cumulative primary energy use for space and tap water heating, and ventilation for the buildings with (marked lines) and without (unmarked lines) improvement, with resistance heating $(\mathrm{RH})$, heat pump (HP) or district heating $(\mathrm{DH})$.

Fig. 3 shows the total cumulative primary energy use of the building with and without the energy efficiency measures but including the primary energy for household electricity. The energy benefits of improvements to the building are still apparent, but are proportionally less significant as the total primary energy use is considered.

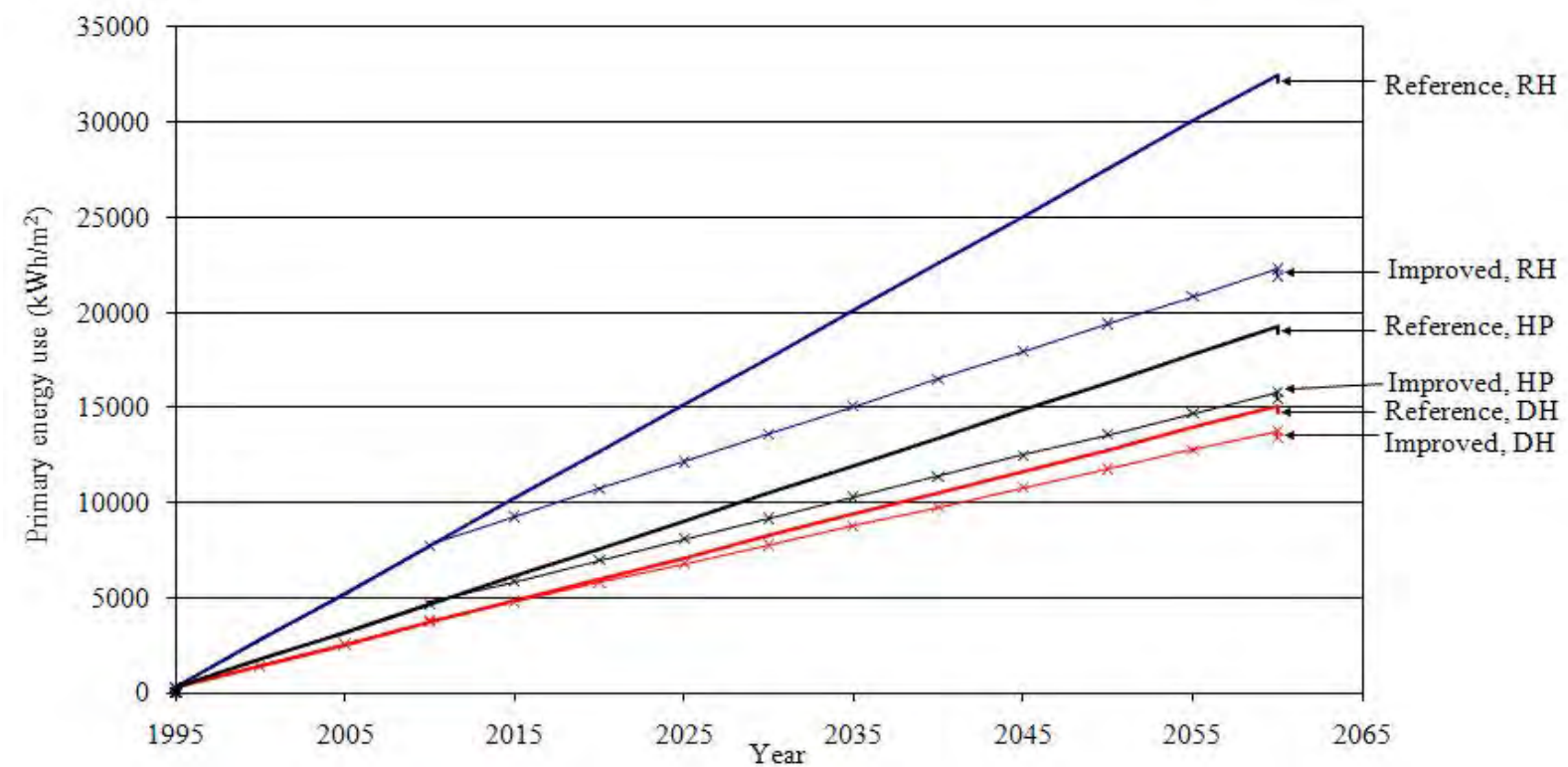

Fig 3. Cumulative primary energy use, for the buildings with and without improvement, including space heating and ventilation as well as energy for household electricity.

Table 5 shows the primary energy use during the life cycle phases of the buildings. The primary energy use during the operation phase dominates, but the relative importance of other life cycle phases increase when the energy efficiency measures are implemented. The primary energy balance during the production phase is relatively small because the primary energy used for material production is largely offset by energy gained from the biomass residues. 
Table 5. Net primary energy use of the life cycle phases of the reference and improved buildings, including the production, operation and end-of-life phases.

\begin{tabular}{|c|c|c|c|c|c|c|}
\hline \multirow[t]{3}{*}{ Life cycle phases } & \multicolumn{6}{|c|}{ Primary energy use } \\
\hline & \multicolumn{2}{|c|}{ Resistance heating } & \multicolumn{2}{|c|}{ Heat pump } & \multicolumn{2}{|c|}{ District heating } \\
\hline & Reference & Improved & Reference & Improved & Reference & Improved \\
\hline Production/retrofitting & 284 & 384 & 284 & 384 & 284 & 384 \\
\hline Operation (50 years) & 24781 & 14481 & 14569 & 11046 & 11365 & 9968 \\
\hline End-of-life & -363 & -369 & -363 & -369 & -363 & -369 \\
\hline Total & 24702 & 14496 & 14490 & 11061 & 11286 & 9983 \\
\hline
\end{tabular}

\section{Discussion and conclusions}

The primary energy savings of different energy efficiency measures depend in part on used heat supply system. Heat recovery from ventilation air is most effective where heat supply is from electricity-based systems. The increase in ventilation electricity, however, erodes part of the primary energy reduction. For heat supply from cogeneration-based district heating, efficient windows and doors are the most effective.

The production primary energy becomes increasingly important as buildings become more energy efficient. Primary energy used for production increases significantly by retrofitting a building, but the resulting reduction in space heating primary energy is much higher, resulting in an overall life cycle primary energy reduction.

The results show that the choice of heat supply system has greater impact on primary energy use than the end-use energy efficiency measures, confirming the results of Gustavsson and Joelsson [5]. Hence, to further minimize primary energy use when buildings are refurbished, priority should be given to energy efficient supply systems such as district heating where possible. When selecting energy efficiency measures, attention should be given to the interaction between individual measures and the type of heat supply system, in particular the electricity use for ventilation heat recovery together with cogeneration-based district heating.

\section{References}

[1] IPCC (Intergovernmental Panel on Climate Change), Climate Change 2007: Mitigation. Contribution of Working Group III to the Fourth Assessment Report, Cambridge University Press, UK, 2007.

[2] M. Bell, Energy efficiency in existing buildings: the role of building regulations, Proceedings of the RICS Foundation Construction and Building Research Conference, 2004.

[3] IEA (International Energy Agency), Energy efficiency requirements in buildings codes, energy efficiency policies for new buildings, 2008. Web accessed at www.iea.org on Nov. 26, 2008.

[4] A. Dodoo, L. Gustavsson, and R. Sathre, Life cycle primary energy implication of retrofitting a Swedish apartment building to passive house standard, Resources, Conservation and Recycling, 54 (12), 2010, pp. 1152-1160.

[5] L. Gustavsson, and A. Joelsson, Life cycle primary energy analysis of residential buildings, Energy and Buildings, 42(2), 2010, pp. 210-220.

[6] S. Persson, Wälludden trähus i fem våningar: Erfarenheter och lärdomar, Report TVBK- 
3032, Department of Structural Engineering, Lund Institute of Technology, Sweden, 1998.

[7] SWEDISOL, Isolerguiden bygg 06, 2006.Web accessed at http://www.stenull.paroc.se on July 7, 2009.

[8] Å. Wahlström, Å. Blomsterberg, and D. Olsson, Värmeåtervinningssystem för befintliga flerbostadshus, Förstudie inför teknikupphandling, 2009.

[9] Swedish Energy Agency, Effektiva kranar sparar energi, 2006. Web accessed at http://www.swedishenergyagency.se on June 17, 2009.

[10]R. Sathre, Life-cycle energy and carbon implications of wood-based products and construction, PhD dissertation, Department of Engineering, Physics and Mathematics, Mid Sweden University, Östersund, Sweden, 2007.

[11] T. Björklund, and A-M. Tillman, LCA of building frame structures: environmental impact over the life cycle of wooden and concrete frames, Technical Environmental Planning Report 2, Chalmers University of Technology, Gothenburg, Sweden, 1997.

[12] T. Björklund, Å. Jönsson, and A-M. Tillman, LCA of building frame structures: environmental impact of the life cycle of concrete and steel frames, Technical Environmental Planning Report 8, Chalmers University of Technology, Gothenburg, Sweden, 1996.

[13] K. Adalberth, Energy Use and Environmental Impact of New Residential Buildings, Ph.D. Dissertation, Department of Building Physics, Lund University, Sweden, 2000.

[14]A. Lehtonen, R. Mäkipää, J. Heikkinen, R. Sievänen, and J. Liski, Biomass expansion factors (BEFs) for Scots pine, Norway spruce and birch according to stand age for boreal forests, Forest Ecology and Management; 188(1-3) , 2004, pp. 211-224.

[15] L. Gustavsson, and R. Sathre, Variability in energy and $\mathrm{CO}_{2}$ balances of wood and concrete building materials, Building and Environment, 41(7), 2006, pp. 940-951.

[16]EQUA (Simulation AB), ENORM, Version 1000, Stockholm, Sweden, 2004.

[17] Å. Karlsson, ENSYST, Version 1.2, Lund University, Sweden, 2003.

[18]L. Gustavsson, and Å. Karlsson, CO2 mitigation: on methods and parameters for comparison of fossil-fuel and biofuel systems, Mitigation and Adaptation Strategies for Global Change, 11(5-6), 2006, pp. 935-959. 